\title{
Hantavirus pulmonary syndrome: Report of four Alberta cases
}

AMEetA E Singh FRCPC, DeNISE H WeRKER FRCPC, LESIA R BOYCHUK FRCPC, LILLY J MiedZINSKI FRCPC

\begin{abstract}
AE SINGH, DH WeRKeR, LR Boychuk, LJ MIedzinski. Hantavirus pulmonary syndrome: Report of four Alberta cases. Can J Infect Dis 1995;6(4):184-190. Four Alberta cases of hantavirus pulmonary syndrome are reported. Three cases required intensive care, with one experiencing a fulminant course resulting in death. A fourth case with milder illness was identified after epidemiological investigations. Ribavirin was used in one patient who experienced a successful outcome. A recent open label trial has not supported the efficacy of this drug. The epidemiology of Peromyscus maniculatus, the primary rodent host, and the clinical features of this syndrome are summarized.
\end{abstract}

Key Words: Alberta, Deer mouse, Hantavirus, Hantavirus pulmonary syndrome, Peromyscus maniculatus

\section{Syndrome respiratoire lié au hantavirus : Rapport sur quatre cas albertains}

RÉSUMÉ : Quatre cas de syndrome respiratoire lié au hantavirus sont présentés ici. Trois ont nécessité des soins intensifs, l'un ayant évolué de façon fulminante jusqu'à la mort. Un quatrième cas, moins grave, a été identifié après une étude épidémiologique. La ribavirine a été administrée à un patient qui s'est rétabli. Un récent essai ouvert n'a pu confirmer l'efficacité de ce médicament. Sont résumés ici l'épidémiologie de Peromyscus maniculatus hébergé par les rongeurs, et les caractéristiques de ce syndrome.

$\mathrm{I}$ N MAY 1993, THE FIRST CASES OF HANTAVIRUS PULMONARY SYNdrome (HPS) were reported from the Four Corners region of the southwestern United States including New Mexico, Arizona, Colorado and Utah (1). As of February 1, 1995, 103 cases have been reported in 21 states with an overall mortality of $52 \%$ (personal communication). The first confirmed cases in Canada were documented in British Columbia between February and June 1994 (2).

In 1994, following media reporting of the American HPS cases, a patient who had been admitted to an Edmonton hospital in 1990 with adult respiratory distress syndrome of unknown etiology wrote to local physicians requesting that his case be reviewed regarding a possible diagnosis of HPS. Stored serum was positive for immunoglobulin (lg) M antibodies to hantavirus. Within the next three months, two further cases were recognized. Epidemiological investigations led to the discovery of a fourth case. We present a description of the clinical courses of the four Alberta cases.

\section{CASE PRESENTATIONS - CASE ONE}

On June 17, 1990 a 42-year-old soldier was admitted to his local hospital with a one-week history of progressive sore throat, rhinorrhea, dry cough, fever, myalgias and dyspnea. In the seven days before becoming unwell, he had been sta-

Division of Infectious Diseases, University of Alberta, Edmonton, Alberta, and British Columbia Centre for Disease Control, Vancouver, British Columbia

Correspondence and reprints: Dr Lilly J Miedzinski, 2E4.17 Walter Mackenzie Health Sciences Centre, University of Alberta Hospital, Edmonton, Alberta T6G 2B7. Telephone 403-492-7313, Fax 403-492-7137, e-mail li@nshade.uah.ualberta.ca

Received for publication March 22, 1995. Accepted March 25, 1995 
TABLE 1

Admission laboratory values of four Alberta cases

\begin{tabular}{|c|c|c|c|c|c|}
\hline & Normal range & Case 1 & Case 2 & Case 3 & Case 4 \\
\hline Absolute leukocyte count $\left(\times 10^{9} / \mathrm{L}\right)$ & $5.0-10.0$ & 24.8 & 40.4 & 5.5 & 12.4 \\
\hline Absolute neutrophil count $\left(\times 10^{9} / \mathrm{L}\right)$ & $2.0-7.5$ & 11.41 & 26.6 & NA & 9.18 \\
\hline Absolute band count $\left(\times 10^{9} / \mathrm{L}\right)$ & $<0.8$ & 5.95 & Nil & 2.69 & 0.12 \\
\hline Absolute myeloblasts/myelocytes $\left(\times 10^{9} / \mathrm{L}\right)$ & 0 & 1.24 & Nil & Nil & Nil \\
\hline Absolute lymphocyte count $\left(\times 10^{9} / \mathrm{L}\right)$ & $1.5-4.0$ & 4.46 & 7.2 & 1.26 & 1.98 \\
\hline Hematocrit & $0.38-0.5$ & 0.52 & 0.47 & 0.47 & 0.5 \\
\hline Platelet count $\left(/ \mathrm{mm}^{3}\right)$ & $150,000-440,000$ & 79,000 & 17,000 & 89,000 & 43,000 \\
\hline Serum sodium $(\mathrm{mmol} / \mathrm{L})$ & $135-150$ & 124 & 130 & 133 & 139 \\
\hline Serum creatinine $(\mu \mathrm{mol} / \mathrm{L})$ & 53-106 & 90 & 165 & 76 & 132 \\
\hline Prothrombin time INR & $0.8-1.2$ & 0.8 & 1.9 & 1.0 & NA \\
\hline Partial thromboplastin time (s) & $26-37$ & 33.5 & 81 & 33.9 & NA \\
\hline $\mathrm{PaO}_{2}^{*}(\mathrm{mmHg})$ & $75-105$ & 55 & $130\left(\mathrm{FiO}_{2} 1.0\right)$ & 44 & 43.2 \\
\hline Bicarbonate (mmol/L) & $24-32(23-28)$ & 34 & 13 & 32 & 25.1 \\
\hline Aspartate aminotransferase $(\mu \mathrm{mol} / \mathrm{L})$ & $10-40$ & 100 & 174 & 84 & 55 \\
\hline Creatinine kinase $(\mu \mathrm{mol} / \mathrm{L})$ & $20-130$ & NA & 582 & 1323 & 164 \\
\hline Lactate dehydrogenase $(\mu \mathrm{mol} / \mathrm{L})$ & $100-225$ & 1493 & 1295 & 1061 & 219 \\
\hline Urine red blood cell count & & $100-200$ & NA & $1-2$ & Moderate \\
\hline Urine white blood cell count & & 5-10 & NA & $1-2$ & NA \\
\hline Urine protein & & $1+$ & NA & $2+$ & $24 \mathrm{~h}>3 \mathrm{~g} / \mathrm{L}$ \\
\hline
\end{tabular}

${ }^{*}$ Room air unless stated; $\mathrm{FiO}_{2}$ Fraction of inspired oxygen; INR International normalized ratio; NA Not available

tioned at a rural camp site, where there had been spraying of biological insecticide. He had also driven a diesel powered tank in which he had been exposed to exhaust fumes. There was no history of recent foreign travel. He later admitted to sharing his tent with deer mice.

Following admission, he was found to be hypoxemic with bilateral interstitial infiltrates on chest $\mathrm{x}$-ray. He was treated with intravenous erythromycin and, as he developed progressive respiratory failure, was intubated and transferred to an Edmonton tertiary care hospital for intensive care.

On examination he had a temperature of $37.7^{\circ} \mathrm{C}$, blood pressure $92 / 50 \mathrm{mmHg}$ and pulse 88 beats/min. Examination of the chest revealed bibasilar crackles. Fraction of inspired oxygen $\left(\mathrm{FiO}_{2}\right)$ of 1.0 was required to maintain adequate oxygenation.

Admission laboratory findings are listed in Table 1. Peripheral smear showed neutrophil leukocytosis with increased band forms and a low platelet count.

A provisional diagnosis of atypical pneumonia was made, with a differential diagnosis of acute insecticide poisoning or hypersensitivity pneumonitis.

Following transfer to the intensive care unit (ICU), the patient was ventilated with progressively higher requirements of inspired oxygen and positive end-expiratory pressure. $\mathrm{He}$ was treated empirically with intravenous erythromycin, cefuroxime and streptomycin. Cardiac monitoring via a Swan Ganz (Edwards Laboratories, Division of Baxter, California) catheter revealed a pulmonary capillary wedge mean pressure of $25 \mathrm{mmHg}$, mean arterial pressure of $62 \mathrm{mmHg}$, cardiac index of $3.28 \mathrm{~L} / \mathrm{min} / \mathrm{m}^{2}$ and systemic vascular resistance index of 1170 dyne $/ \mathrm{sec} / \mathrm{cm}^{-5} / \mathrm{m}^{2}$ Several pneumothoraces were drained. Bronchoscopy revealed no gross abnormalities.
By day 5 of admission, the patient's oxygenation had improved. By day 7 , chest x-ray also showed marked improvement and $\mathrm{FiO}_{2}$ had decreased to 0.45 . After this initial improvement, oxygenation once again deteriorated and he became hemodynamically unstable requiring inotropic support. Chest $\mathrm{x}$-ray showed bilateral air space consolidation and he was given intravenous piperacillin and tobramycin as empirical treatment for presumed nosocomial pneumonia.

An open lung biopsy on day 12 showed chronic diffuse alveolar injury and hyaline membranes consistent with adult respiratory distress syndrome of probable viral etiology.

Intravenous methylprednisolone was commenced on day 13 at $1 \mathrm{~g}$ intravenously daily for three days. By day 14 , he had again improved with $\mathrm{FiO}_{2}$ reduced to 0.6. Chest $\mathrm{x}$-ray still showed bilateral air space consolidation.

On day 17 , a tracheostomy was performed. On day 22, increasing purulent secretions and an elevated temperature with new alveolar consolidation on chest $\mathrm{x}$-ray prompted a second diagnosis of nosocomial pneumonia. He was treated for Escherichia coli isolated from sputum. His ICU stay was further complicated by the development of a large pulmonary embolus, which required thrombolysis.

He was weaned from the ventilator on day 73 , when his main problems included generalized weakness due to loss of muscle mass and mild peripheral neuropathy of undetermined etiology. Pulmonary function tests before discharge on day 81 revealed a restrictive defect with reduced diffusing capacity.

Bronchoscopy specimens from early admission were negative on direct microscopic examination and culture for acid-fast bacilli, fungi and bacteria including legionella. Silver stain for Pneumocystis carinii was negative. Serology for in- 
fluenza $A$ and $B$, adenovirus, herpes simplex virus, acute and convalescent tularemia and mycoplasma were all negative. Cytology revealed atypical alveolar cells.

A retrospective diagnosis of HPS was made in 1994 by testing for hantavirus antibodies. Both IgM antibodies from stored serum and IgG antibodies from fresh serum were positive for Sin Nombre virus at titres greater than 1:1600 by enzyme immunoassay (EIA). Lung tissue from the original open lung biopsy was also positive by immunohistochemical staining for hantavirus (personal communication).

\section{CASE TWO}

A 55-year-old male was transferred to an Edmonton hospital from a rural hospital on October 4, 1994. One week before transfer, he had developed fever, nausea, vomiting, diarrhea and a nonproductive cough. On October 2, he was seen at the emergency department of his local hospital where he was treated with intravenous fluids for a presumed gastroenteritis and discharged home.

The following day he was admitted to the same hospital after presenting with worsening respiratory symptoms. Chest $x$-ray showed patchy left lower lobe consolidation, and he was started on intravenous penicillin and erythromycin. He had a pulse rate of 104 beats $/ \mathrm{min}$, temperature of $38.1^{\circ} \mathrm{C}$ and respiratory rate of 56 breaths/min. Laboratory findings included hemoglobin of $156 \mathrm{~g} / \mathrm{L}$, leukocyte count of $15.2 \times 10^{9} / \mathrm{L}$ with a left shift and platelet count of $50 \times 10^{9} / \mathrm{L}$. Serum sodium was 130 $\mathrm{mmol} / \mathrm{L}$ and glucose was $15.2 \mathrm{mmol} / \mathrm{L}$.

The patient developed progressive respiratory distress requiring intubation and transfer to a city hospital ICU the following morning. Before transfer, he received intravenous methylprednisolone and inhaled bronchodilators.

Further history obtained from the patient's wife indicated that two weeks earlier, he had trapped a mouse in a kitchen cupboard on their acreage. He had disposed of the mouse by throwing it beyond their backyard and had vacuumed the droppings from the back of the cupboard. The only history of travel was to British Columbia in June of that year.

Past medical history was remarkable for remote alcohol abuse and peptic ulcer disease. He was a forty pack-year smoker.

On examination after transfer, the patient was markedly diaphoretic with diffuse skin mottling. Pulse rate was 130 beats/min, blood pressure was $90 / 60 \mathrm{mmHg}$ and body temperature was $38.5^{\circ} \mathrm{C}$. He had pinpoint pupils, scleral edema and a palpable left submandibular lymph node. Chest examination revealed coarse, diffuse crackles.

Laboratory findings are shown in Table 1. Peripheral smear showed leukocytosis with atypical lymphocytes. Chest $x$-ray revealed extensive air space consolidation. HPS was included in the differential diagnosis of atypical pneumonia.

Following admission, the patient was started on ceftazidime, erythromycin and pressor agents. Bronchoscopy revealed a diffusely inflamed and bronchospastic airway with no endobronchial lesions. After initially appearing to stabilize, his condition deteriorated rapidly with hypotension unrespon- sive to intravenous fluids and pentastarch. He received a total of $24 \mathrm{~L}$ of fluid during admission.

He developed severe metabolic acidosis (serum lactate rising to $20.4 \mathrm{mmol} / \mathrm{L}$ ) unresponsive to sodium bicarbonate, coagulopathy with prothrombin time international normalized ratio rising to greater than 7 , partial thromboplastin time to $129 \mathrm{~s}$ and renal dysfunction with serum creatinine rising to $312 \mu \mathrm{mol} / \mathrm{L}$. He died $30 \mathrm{~h}$ following admission.

Postmortem examination was limited to a liver biopsy due to concerns regarding biosafety. Histology showed mild steatosis and prominent hepatic congestion with mild reactive changes in the hepatocytes.

Bacterial cultures from bronchoscopy specimens grew mixed oropharyngeal flora and small amounts of yeast as well as Hafnei alvei. Direct fluorescent antibody testing and cultures for Chlamydia pneumoniae, Legionella pneumophila, adenovirus, parainfluenza virus and cytomegalovirus were negative. Cytology was negative for malignant cells and $P$ carinii. Cultures for Mycoplasma pneumoniae and acid-fast bacilli were also negative. Serology for $M$ pneumoniae, $C$ pneumoniae and $L$ pneumophila were also negative.

The diagnosis of HPS was subsequently confirmed with positive IgM antibodies to Sin Nombre virus by EIA.

\section{CASE THREE}

On October 19, 1994, a 32-year-old farmer was admitted to a local hospital. Since the spring of that year, he had been intermittently unwell, with several episodes of fever and influenza-like illness. Three days before admission, he developed a fever to $39.9^{\circ} \mathrm{C}$, chills, rigors and neck stiffness. He was admitted with a diagnosis of febrile illness of unknown etiology and treated with acetaminophen and cephalexin. Admission chest $\mathrm{x}$-ray was normal.

Due to persistently elevated temperature and lack of clinical response to empirical antibiotic therapy, he was transferred to an Edmonton hospital on October 21. Chest x-ray before transfer showed increased linear markings in the perihilar regions and fluid in the fissures. When seen in the emergency department, he complained of a bifrontal headache, nonproductive cough and dysuria. Past history was noncontributory.

On initial examination after transfer, he was diaphoretic. Temperature was $39.9^{\circ} \mathrm{C}$, pulse rate was 118 beats $/ \mathrm{min}$, blood pressure was $140 / 50 \mathrm{mmHg}$ and respiratory rate was 28 breaths/min. Chest examination revealed crepitations at the right lung base.

Laboratory findings on admission are summarized in Table 1. Peripheral smear showed moderate thrombocytopenia with a shift to the left in polymorphs and a few reactive lymphocytes. Chest x-ray showed worsening bilateral interstitial infiltrates.

Further inquiry determined that in the two months before becoming unwell, the patient had had repeated exposure to mice and their nests and droppings during his farm work. HPS was suspected.

He received intravenous erythromycin and cefuroxime and oxygen by mask. During the course of the evening, he be- 
came progressively more dyspneic and developed hemoptysis. Arterial blood gases on $10 \mathrm{~L}$ of oxygen by mask showed $\mathrm{PaO}_{2}$ of $48 \mathrm{mmHg}, \mathrm{PaCO}_{2}$ of $31 \mathrm{mmHg}$ and oxygen saturation of $86 \%$. He was transferred to the ICU and intubated. In the early hours of the following day, he developed tension pneumothorax, requiring chest tube placement. Bronchoscopy did not show any gross abnormalities. By the following morning, he required an $\mathrm{FiO}_{2}$ of 1.0 and inotropic support.

His oxygen saturation deteriorated to $84 \%$ on an $\mathrm{FiO}_{2}$ of 1.0 and he developed worsening pulmonary infiltrates. He received intravenous methylprednisolone $1 \mathrm{~g}$ at 14:30 h. Six hours later, he had improved with an oxygen saturation of $91 \%$ on an $\mathrm{FiO}_{2}$ of 1.0 . He developed lactic acidosis with serum lactate peaking at $3.3 \mathrm{mmol} / \mathrm{L}$, which was treated with intravenous bicarbonate. Intravenous ribavirin was started.

The patient improved progressively over the next few days, with $\mathrm{FiO}_{2}$ decreased to 0.5 by day 4 ; he was off all inotropes by day 5 . White blood cell count peaked at $9.7 \times 10^{9} / \mathrm{L}$ with a marked left shift and serum creatinine at $145 \mu \mathrm{mol} / \mathrm{L}$. Antibiotics were discontinued after negative culture results were obtained. He received three doses of methylprednisolone $1 \mathrm{~g}$ intravenously daily and a five-day tapering course of intravenous ribavirin.

On day 7 , the patient was successfully extubated with chest $x$-ray showing almost complete resolution of infiltrates. He was discharged from hospital seven days later.

Bronchoscopy results from admission showed negative direct fluorescent antibody testing for legionella, chlamydia, parainfluenza and adenovirus. Direct examination and cultures for bacteria, fungi and mycobacteria were negative as was silver stain for $P$ carinii. Two sets of blood cultures, serology for human immunodeficiency virus and mycoplasma IgM antibodies were negative as was cytology for malignant cells.

When seen at follow-up six weeks later, the patient was diagnosed with hypertension and was started on antihypertensive agents. He was noted to have a strongly positive family history for hypertension. Pulmonary function tests were normal and complete blood count and serum creatinine had normalized.

A diagnosis of HPS was confirmed two weeks later by positive serum IgM antibodies to Sin Nombre virus with a titre greater than $1: 1600$ by EIA.

\section{CASE FOUR}

A 42-year-old farmer with a past history of hypertension was admitted to a community hospital on October 21, 1994 with headache and stiff neck. He had been well until three weeks before admission when he developed increasing shortness of breath, orthopnea and productive cough. He denied fevers or chills. His symptoms settled after a week and he remained well until two days before admission when he developed sudden onset of chills with left chest heaviness and nausea.

He indicated that a neighbour had recently been admitted to an Edmonton hospital with HPS (case 3). The patient had also been repeatedly exposed to mice during farming activities. This included the cleaning of a hot water tank that had become infested with mice and the feeding of cattle in barns where the presence of numerous mice was noted.

On admission, the patient had a temperature of $39.6^{\circ} \mathrm{C}$ and blood pressure of $230 / 130 \mathrm{mmHg}$. He had discontinued antihypertensive medication for eight months for financial reasons. Initial laboratory findings are listed in Table 1. Chest $x-$ ray on October 21 was reported as normal. Repeat chest $x-$ ray on October 24 showed right middle lobe atelectasis. He required oxygen by mask and was treated with oral ciprofloxacin and captopril.

He was transferred to an Edmonton hospital on October 29 for further assessment of renal dysfunction and 'pneumonitis'. He was admitted with diagnoses of accelerated hypertension and atypical pneumonia.

Past history was noncontributory. He had not smoked for 20 years.

On admission, temperature was $37.0^{\circ} \mathrm{C}$, pulse 92 beats/min, blood pressure $138 / 102 \mathrm{mmHg}$. Examination of the chest revealed a few diffuse crackles. His liver edge was palpable and he had mild bilateral pedal edema.

Laboratory findings included an absolute leukocyte count of $11.1 \times 10^{9} / \mathrm{L}$ with $55 \%$ neutrophils and $2 \%$ bands, hemoglobin $169 \mathrm{~g} / \mathrm{L}$ and platelet count $193,000 / \mathrm{mm}^{3}$. Serum creatinine was $113 \mu \mathrm{mol} / \mathrm{L}$. $\mathrm{PaO}_{2}$ was $51 \mathrm{mmHg}$ with $\mathrm{PaCO}_{2} 26$ $\mathrm{mmHg}$. Aspartate aminotransferase was $124 \mu \mathrm{mol} / \mathrm{L}$ and lactate dehydrogenase $657 \mu \mathrm{mol} / \mathrm{L}$. Urinalysis showed no red blood cells, zero to two white blood cells and trace protein. Chest x-ray on October 29 showed patchy bronchopneumonia in the right lower lobe and a small right pleural effusion. Sputum for routine bacterial culture showed no growth. After transfer, he remained afebrile throughout hospitalization.

$\mathrm{He}$ was treated with antihypertensive agents and discharged five days later following resolution of his respiratory symptoms and control of his blood pressure. Before discharge, oxygen saturation on room air was $94 \%$.

Based on the patient's clinical condition following transfer, HPS was not suspected and was diagnosed retrospectively after epidemiological investigations. Stored serum was reactive for IgM antibodies to Sin Nombre virus by EIA.

\section{DISCUSSION}

Before the initial reports of HPS in the United States, all known hantavirus infections were collectively called hemorrhagic fever with renal syndrome (3); this term includes the syndromes referred to as nephropathica epidemica in Scandinavia and epidemic hemorrhagic fever in Asia. These syndromes consist of predominantly renal and hemorrhagic complications, but a few cases have been described with coexisting or primarily pulmonary pathology (4). Since the recognition of HPS, a few retrospective cases of hemorrhagic fever with renal syndrome have been identified in the mainland United States (5). HPS has been characterized by a predominance of respiratory symptoms (6). The typical picture is one of rapidly developing noncardiogenic pulmonary edema. Recent reviews and case reports have summarized the clinical and epidemiological findings (7-9).

The etiological agent of HPS in the southwest United States 
is a member of the genus hantavirus, which is a group of tripartite RNA viruses in the Bunyaviridae family (10). The agent implicated in the majority of cases was isolated from the lung tissue of a deer mouse and was initially called Muerto Canyon virus after the area in New Mexico where the first cases were identified (11). This has subsequently been renamed Sin Nombre virus (12). At least two other distinct viruses have been implicated - Black Creek Canal virus and Bayou virus $(13,14)$.

Hantaviruses are known to infect rodents in which they produce asymptomatic chronic infection with viral shedding in urine, feces and saliva (15). Rodent to human transmission occurs primarily by inhalation of infected rodent excretions. Person to person transmission has not been documented. Laboratory transmission of hantaviruses has been described with infected animals and cell culture (16). Biosafety level 2 laboratories are recommended to handle potentially infected serum and tissue and level 3 laboratories for virus propagation $(16,17)$.

The primary reservoir host of Sin Nombre virus is the deer mouse, Peromyscus maniculatus (18). The seroprevalence of antibodies to hantavirus in a sample population of this species in the Four Corners area was $20 \%$. This species inhabits most of the United States and Canada except the southeast and Atlantic seaboard of the United States and the extreme north of Canada $(2,14)$. The occurrence of cases outside the range of peromyscus has been attributed to the presence of related but genetically distinct viruses in other rodent species. For example, in Florida, the Black Creek Canal Virus has been isolated from the rodent species, Sigmodon hispidus (14). Although mice have not been tested in the area where our cases occurred, the seropositivity for hantavirus antibodies in $P$ maniculatus tested in Alberta ranged from 1.2 to $19.6 \%$ in four areas where mice were trapped (personal communication). All four Alberta cases originated from the same region of east central Alberta. Climatic changes resulting in increases in the deer mouse population have been implicated in the clustering of cases in the Four Corners area (19). The specific ecological factors contributing to the Alberta cases have not been elucidated but anecdotal reports suggest an increase in the mouse population in the fall of 1994.

Our four cases illustrate a spectrum of illness ranging from mild symptoms to death. They demonstrate the characteristic prodromal findings of fever, cough, dyspnea, gastrointestinal symptoms and headache. Common physical findings include tachycardia, tachypnea and hypotension. Characteristic laboratory findings may give the first clue to the diagnosis and include leukocytosis with a left shift, hemoconcentration, thrombocytopenia, prolonged prothrombin and partial thromboplastin times, elevated lactate dehydrogenase, decreased serum protein and proteinuria (8). Mild elevations in serum creatinine are commonly seen as demonstrated by our cases. A case control study carried out by the Centers For Disease Control and Prevention ([CDC] Atlanta, Georgia) suggested that the combination of four symptoms (myalgias, dizziness, cough, nausea/vomiting) and three laboratory findings (hematocrit, platelet count and bicarbonate level) applied to patients with fever, tachypnea and nonlobar radiographic infiltrates accurately differentiated patients with HPS from control subjects (20). These findings require further validation. No rapid diagnostic test is available.

Normal or elevated systemic vascular resistance and normal or reduced cardiac output have been reported as typified by case 1 . These findings are in contrast to the changes seen with bacterial sepsis. Chest $\mathrm{x}$-ray findings include significant interstitial edema with progression to airspace disease within $48 \mathrm{~h}$ in the majority of patients (21). Pleural effusions are also commonly seen.

Subclinical and mild disease is said to be uncommon (9). In more than 500 residents of the Four Corners area who were asymptomatic or had mild illness, specific hantavirus antibody prevalence was $1 \%$ (22). Case 4 experienced a milder form of disease and his presentation was complicated by coexisting accelerated hypertension. With the nonspecificity of initial symptoms and physical signs, the diagnosis may be difficult with only a history of exposure to deer mice or mouse droppings to hint at the diagnosis.

Once HPS is recognized, optimal management consists of prompt control of hypoxia, which can deteriorate rapidly, the early use of inotropic agents and avoidance of excessive fluid administration $(6,8)$. Ribavirin is an antiviral drug that inhibits the replication of several hantaviruses. Prospective doubleblind clinical trials of ribavirin in China in patients with hemorrhagic fever with renal syndrome demonstrated a sevenfold reduction in mortality among treated patients (23). The CDC carried out an open label trial of intravenous ribavirin in patients with suspected HPS. A review of the results did not demonstrate a clear benefit and the trial was terminated (14). The $\mathrm{CDC}$ is no longer advocating its use but randomized controlled trials have yet to be performed.

Although hypertension has been associated with other hantaviruses (24), it has not been reported as a complication of HPS. The development of hypertension in case 3 may have been associated with this disease but his family history of hypertension makes essential hypertension more likely.

Various activities have resulted in HPS infection, including planting or harvesting field crop, occupying previously vacant barns or outbuildings, cleaning barns or other outbuildings, disturbing rodent-infested areas while hiking or camping, inhabiting dwellings with indoor rodent populations and residing in or visiting areas with increased rodent density $(25,26)$. All our cases had documented exposure to deer mice.

Finally, given the significant presence of the reservoir host for HPS in Canada, it is likely that more cases will be identified. As eradication of the primary host is neither feasible nor advisable (25), it is important to reduce human contact with potentially infected rodents. Interim guidelines to reduce the risk of infection have been published by the CDC (25) and adapted by Canadian authorities (16). 
ACKNOWLEDGEMENTS: We thank all those who contributed to the management of the Alberta cases, including Drs D Callaghan and W Dickout, Misericordia Hospital; Drs WDN Chin and M Joffe, University of Alberta Hospital; Dr I Ferguson, Royal Alexandra Hospital; Dr J Waters, Provincial Epidemiologist, Alberta Health; Dr H Artsob, National Laboratory for Special Pathogens, LCDC; Dr J Preiksaitis and Mr E Prasad, Provincial Laboratory, Alberta Health; Dr W Moulaison, Department of National Defence; Dr Savard, Stony Plain Hospital; Dr H Murray, Wainwright Health Care Complex; Dr E York, Wetaskiwin Hospital; Dr S Zaki, Centers for Disease Control and Prevention, Atlanta.

\section{REFERENCES}

1. Centers for Disease Control and Prevention. Outbreak of acute illness - Southwest United States, 1993. MMWR 1993;42:421-4.

2. First reported cases of hantavirus pulmonary syndrome in Canada. Can Commun Dis Rep 1994;20-15:121-5.

3. Settergren B. Nephropathica epidemica (hemorrhagic fever with renal syndrome) in Scandinavia. Rev Infect Dis 1991;13:736-44.

4. Clement J, Colson P, McKenna P. Hantavirus pulmonary syndrome in New England and Europe. N Engl J Med 1994;331:545-6. (Lett)

5. Glass GE, Watson AJ, Leduc JW, Childs JE. Domestic cases of hemorrhagic fever with renal syndrome in the United States. Nephron 1994;68:48-51.

6. Centers for Disease Control and Prevention. Update: hantavirus pulmonary syndrome - United States, 1993. MMWR 1993;42:816-20.

7. Butler JC, Peters CJ. Hantaviruses and hantavirus pulmonary syndrome. Clin Infect Dis 1994;19:387-95.

8. Duchin JS, Koster FT, Peters CJ, et al. Hantavirus pulmonary syndrome: a clinical description of 17 patients with a newly recognised disease. N Engl J Med 1994;330:949-55.

9. Shefer AM, Tappero JW, Bresee JS, et al. Hantavirus pulmonary syndrome in California: report of two cases and investigation. Clin Infect Dis 1994;19:1105-9.

10. Johnson KM. Hantaviruses. In: Evans AS, ed. Viral Infection of Humans, 3rd edn. New York: Plenum Publishing Corp, 1991:341-50.

11. Elliott $L H$, Ksiazek TG, Rollin PE, et al. Isolation of the causative agent of hantavirus pulmonary syndrome.

Am J Trop Med Hyg 1994;51:102-8.

12. Centers for Disease Control and Prevention. Hantavirus pulmonary syndrome - Virginia, 1993. MMWR 1994;43:876-7.
13. Centers for Disease Control and Prevention. Newly identified hantavirus - Florida, 1994. MMWR 1994;43:99-105.

14. Centers for Disease Control and Prevention. Hantavirus pulmonary syndrome - northeastern United States, 1994. MMWR 1994;43:548-9,555-6.

15. Lee HW, Pyung WL, Baek LJ, et al. Intraspecific transmission of hantaan virus, etiologic agent of Korean hemorrhagic fever in the rodent Apodemus agrarius. Am J Trop Med Hyg 1981;30:1106-12.

16. Recommendations for hantavirus risk reduction. Can Commun Dis Rep 1994;20-15:126-8.

17. Centers for Disease Control and Prevention. Laboratory mangement of agents associated with hantavirus pulmonary syndrome: interim biosafety guidelines. MMWR 1994;43:RR-7.

18. Childs JE, Ksiazek TG, Spiropoulou CF, et al. Serologic and genetic identification of Peromyscus maniculatus as the primary rodent reservoir for a new hantavirus in the southwestern United States. J Infect Dis 1994;169:1271-80.

19. Sinnott JT, Greene JN, Kim E, Gompf S. Hantavirus: an old bug learns new tricks. Infect Control Hosp Epidemiol 1993;14:661-4.

20. Moolenar RL, Dalton C, Lipman HB, et al. Clinical features distinctive of hantavirus pulmonary syndrome. Abst J257. 34th Interscience Conference on Antimicrobial Agents and Chemotherapy, Orlando, October 4 to 7, 1994.

21. Ketai LH, Williamson MR, Telepak RJ, et al. Hantavirus pulmonary syndrome (HPS): radiographic findings in 16 patients. Radiology 1994;191:665-8.

22. Duchin JS, Breiman RF, Butler JC, Peters CJ. Hantavirus pulmonary syndrome in New England and Europe. N Engl J Med 1994;331:547. (Lett)

23. Huggins JW, Hsiang CM, Cosgriff TM, et al. Prospective, double-blind, concurrent, placebo-controlled clinical trial of intravenous ribavirin therapy of hemorrhagic fever with renal syndrome. J Infect Dis 1991;164:1119-27.

24. Glass GE, Watson AJ, Leduc JW, et al. Infection with a ratborne hantavirus in US residents is consistently associated with hypertensive renal disease. J Infect Dis 1993;167:614-20.

25. Centers for Disease Control and Prevention. Hantavirus infection - southwestern United States: interim recommendations for risk reduction. MMWR 1993;42:RR-11.

26. Zeitz PS, Butler JC, Cheek JE, et al. Risk factors for hantavirus pulmonary syndrome (HPS) during an outbreak in the southwestern United States. Abst J258. 34th Interscience Conference on Antimicrobial Agents and Chemotherapy, Orlando, October 4 to 7, 1994. 


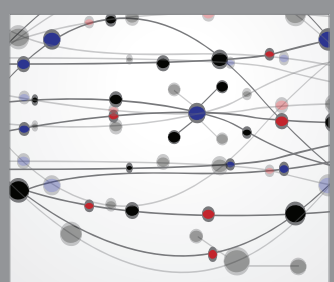

The Scientific World Journal
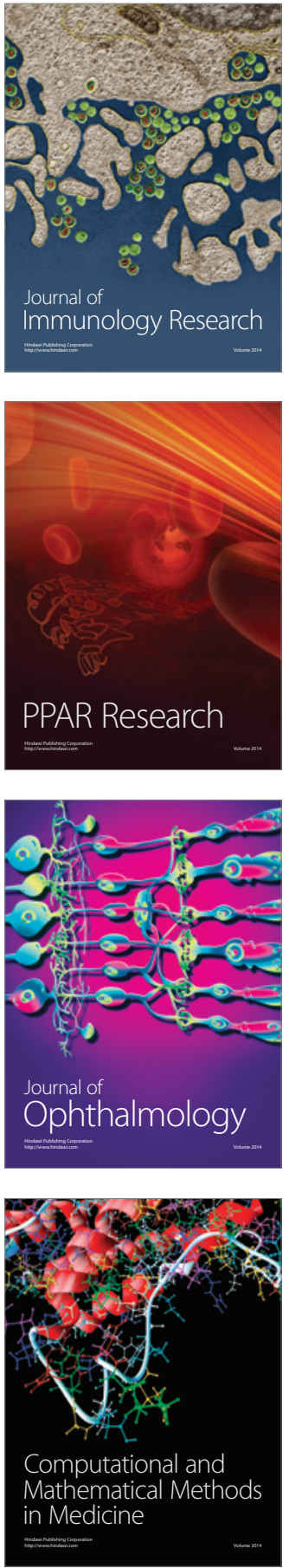

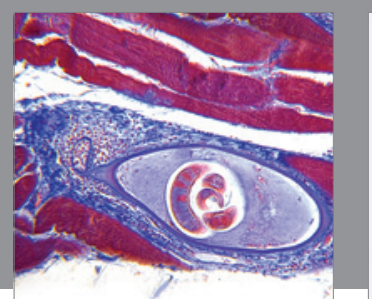

Gastroenterology Research and Practice

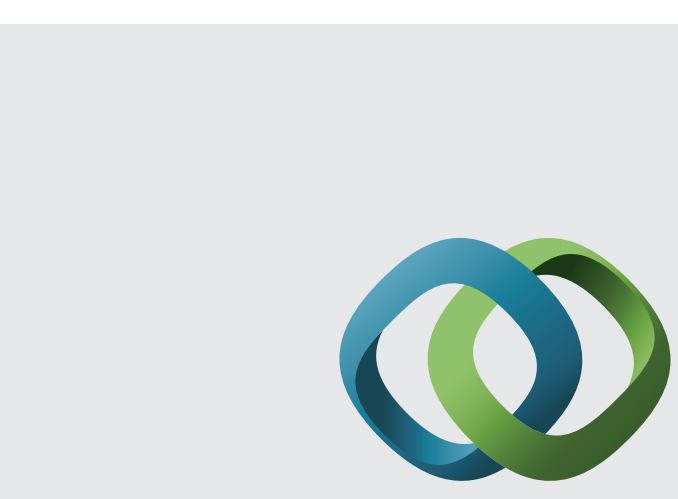

\section{Hindawi}

Submit your manuscripts at

http://www.hindawi.com
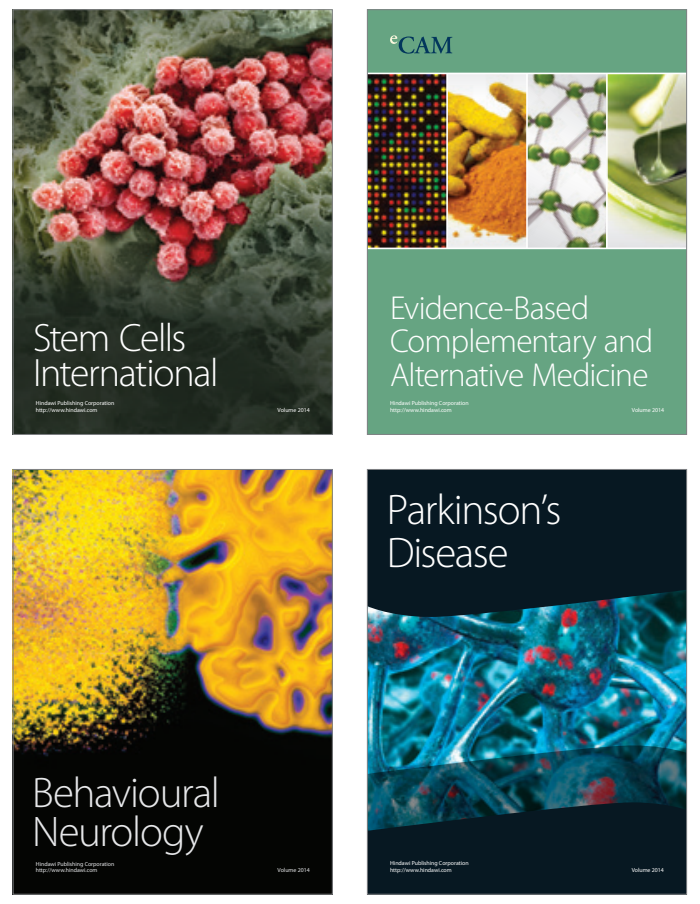
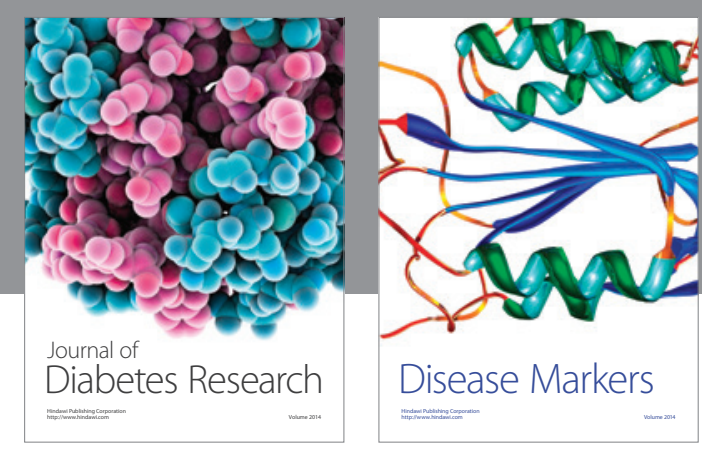

Disease Markers
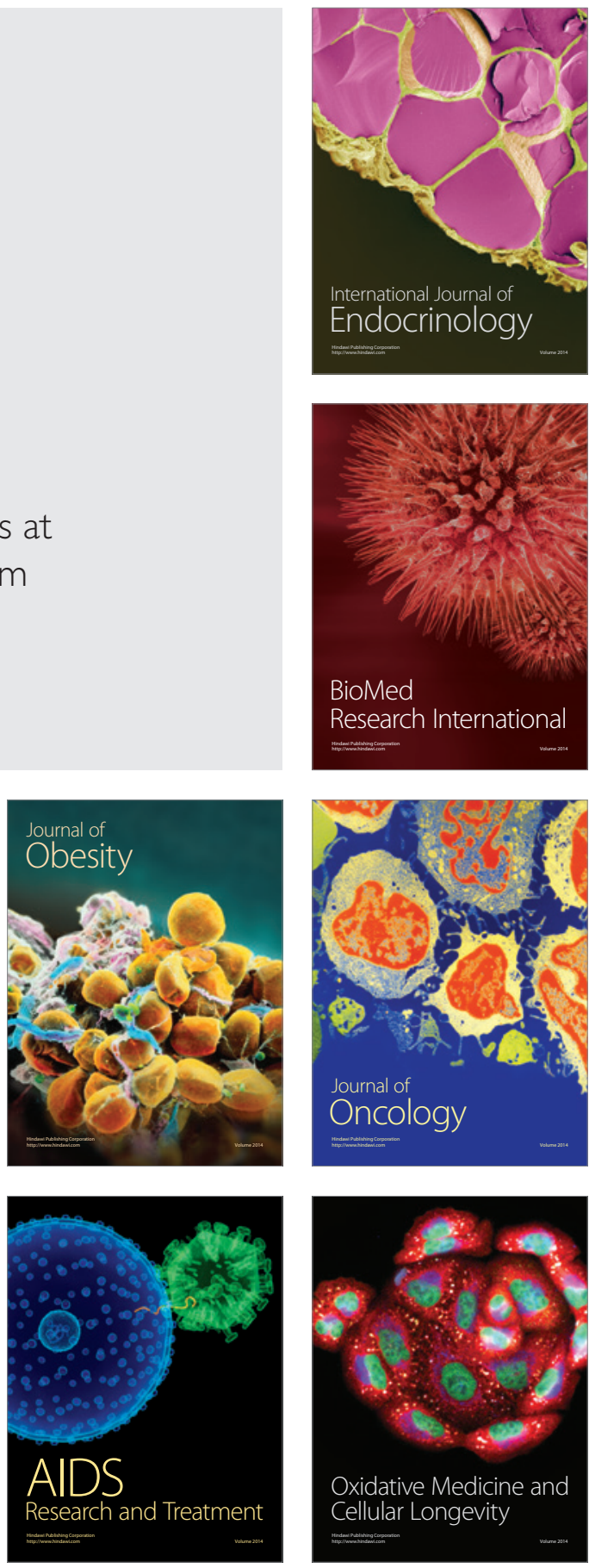